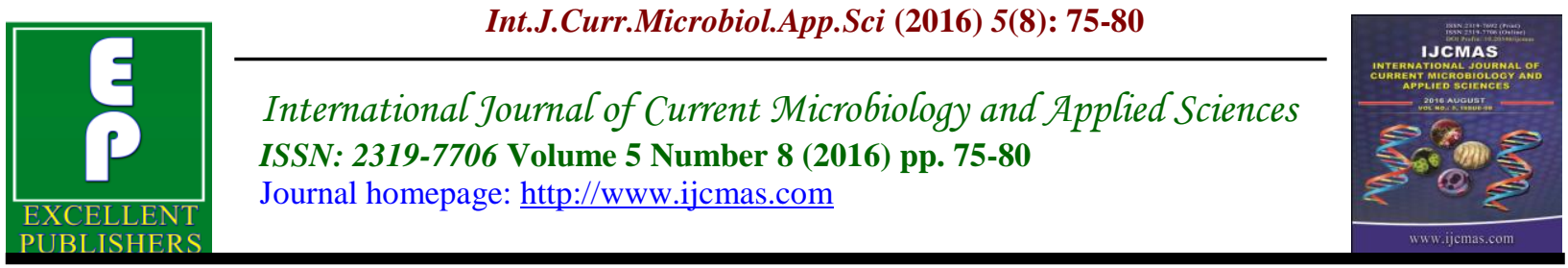

Case Study

http://dx.doi.org/10.20546/ijcmas.2016.508.009

\title{
Escherichia coli in Pleural Empyema - An Uncommon Isolation
}

\author{
Malathi Murugesan $^{1 *}$, Vijayalakshmi Arumugam ${ }^{1}$ and Nithya Gomatheswari ${ }^{2}$ \\ ${ }^{1}$ Department of Microbiology, Chengalpattu Medical College, Chengalpattu, Tamil Nadu, India \\ ${ }^{2}$ Department of Microbiology, Thoothukudi Medical College, Thoothukudi, Tamil Nadu, India \\ *Corresponding author
}

\begin{tabular}{|c|c|}
\hline & A B S T R A C T \\
\hline $\begin{array}{l}\text { K e y w o r d s } \\
\text { Escherichia coli, } \\
\text { Pleural Empyema } \\
\text { cholecysitis, } \\
\text { bacteremia, } \\
\text { meningitis. }\end{array}$ & \multirow{3}{*}{$\begin{array}{l}\text { Escherichia coli is the most frequent causative agent isolated in purulent } \\
\text { infections, urinary tract infections, cholecysitis, bacteremia, meningitis and } \\
\text { in traveler's diarrhoea. Isolation of Escherichia coli from pleural space is } \\
\text { uncommon. In this report, we present a case of Escherichia coli causing } \\
\text { pleural empyema. E.coli may cause severe illness requiring more aggressive } \\
\text { treatment such as appropriate antibiotic and decortication. Thus, diagnostic } \\
\text { thoracentesis should be carried out in any patient who presents with fever, } \\
\text { pleuritic pain or unexplained signs with hydrothorax. This paves a way for } \\
\text { proper antibiotic to be given, to avoid prolongation of illness and to prevent } \\
\text { the emergence of resistant strains. }\end{array}$} \\
\hline Article Info & \\
\hline $\begin{array}{l}\text { Accepted: } \\
\text { 06 July } 2016 \\
\text { Available Online: } \\
10 \text { August } 2016\end{array}$ & \\
\hline
\end{tabular}

\section{Introduction}

Pleural empyema is the collection of purulent fluid in the pleural space. The incidence of pneumonia has decreased in the recent years due to antibiotic usage. However, the incidence of pleural infections is increasing worldwide (Burgos et al., 2013). Pleural infections are most commonly caused by Gram positive cocci, anaerobic bacteria and tuberculous infection. Escherichia coli is the most frequent causative agent isolated in purulent infections, urinary tract infections, cholecysitis, bacteremia, meningitis and in traveler's diarrhoea. Isolation of Escherichia coli from pleural space is uncommon.
In this report, we present a case of Escherichia coli causing pleural empyema.

\section{Case Definition}

Thoracic empyema is defined as pleural effusion that fulfilled at least one of the following criteria:

1.The presence of frank pus on pleural aspiration

2. Presence of organism on culture

3. Positive pleural fluid Gram stain

\section{Case Description}

A 20 years old male, admitted with 
complaints of pain in the right side of abdomen for three days and high grade fever for one day. The patient was provisionally diagnosed as right ureteric colic and was started on ciprofloxacin 500mg i.v bd, analgesics and fluid supplements. Routine investigations was done (Table1).

Patient had not shown any response to treatment and the antibiotic was switched over to Cefotaxime i.v 500mg bd. After seven days of treatment, he had intermittent abdominal pain and high grade fever and was shifted to IMCU and was started on metronidazole $500 \mathrm{mg}$ i.v bd. Imaging modalities of investigation were done (Table 2). Pleural fluid tapping was done under aseptic precautions and sent to microbiology department for culture and sensitivity.

On direct Gram staining, numerous pus cells with abundant gram negative bacilli were seen (Figure 3). On Ziehl Neelsen staining, no acid fast bacilli was seen. Conventional culture showed Escherichia coli which was confirmed by its colony morphology, motility test and biochemical reactions. The antibiotic susceptibility testing showed resistance to first line drugs. ESBL was confirmed by Double disk method according to CLSI guidelines.

The isolate was sensitive to Meropenam. Hence it was diagnosed as a case of acute viral fever with polyserositis complicated by ESBL producing Escherichia coli causing pleural empyema.

\section{Results and Discussion}

Pleural empyema is a serious complication of pneumonia or infection of adjacent sites that resolves only by appropriate antibiotic or by drainage or by decortication. The incidence of pleural empyema has increased worldwide. In a study conducted in the United States, where the frequency was 3.96 cases per 100000 in 1996 has been increased to 8.10 cases per 100000 in 2008 (Bryant et al., 1996).

The microbiological profile of pleural infections vary depends upon the source of infection, host factors and environment. Immuno-compromised persons are more prone for fungal and Gram negative aerobic infections.

In healthy adults, the most common etiological agents are Streptococcus pneumoniae, S.pyogenes and Staphylococcus aureus and Klebsiella pneumonia (Brims et al., 2010). Escherichia coli causing pleural empyema is rare in healthy adults. Bacteria in the empyema release $\beta$-lactamase capable of degrading $\beta$ lactam antibiotics and are relatively unresponsive to antibiotics.

Previous study conducted by Nick A Maskell et al., showed that approximately $50 \%$ of community-acquired infections were streptococcal, and $20 \%$ by anaerobic bacteria.

Hospital-acquired infections accounted for $60 \%$ which included bacteria frequently resistant to antibiotics. Mortality rate was also increased in hospital-acquired infections (Nick et al., 2006). In our case report, we have presented a healthy adult, with no risk factors for developing empyema was diagnosed with ESBL producing Escherichia coli causing pleural empyema. It is a very uncommon isolation when compared with data in various studies (Kundu et al., 2010). 


\begin{tabular}{|l|l|}
\hline \multicolumn{2}{|c|}{ Table.1 Baseline investigation report } \\
\hline Hemoglobin & $10 \mathrm{gms} \%$ \\
\hline Total WBC count & 12,200 cells/cu.mm \\
\hline Polymorphonuclear cells & $65 \%$ \\
\hline Lymphocytes & $32 \%$ \\
\hline Eosinophils & $03 \%$ \\
\hline Total protein & $7 \mathrm{~g} / \mathrm{dl}$ \\
\hline Serum albumin & $3.8 \mathrm{~g} / \mathrm{dl}$ \\
\hline Random blood sugar & $89 \mathrm{mg} / \mathrm{dl}$ \\
\hline Serum creatinine & $0.6 \mathrm{mg} / \mathrm{dl}$ \\
\hline Blood urea & $27 \mathrm{mg} / \mathrm{dl}$ \\
\hline Serum bilirubin & $1.1 \mathrm{mg} / \mathrm{dl}$ \\
\hline SGOT & $16 \mathrm{U} / \mathrm{L}$ \\
\hline SGPT & $19 \mathrm{U} / \mathrm{L}$ \\
\hline ALP & $68 \mathrm{U} / \mathrm{L}$ \\
\hline
\end{tabular}

\begin{tabular}{|l|l|}
\hline \multicolumn{2}{|c|}{ Table.2 Imaging Reports } \\
\hline Ultrasound - abdomen and pelvis & $\begin{array}{l}\text { Free fluid in the peritoneal cavity; Appendix appear } \\
\text { inflamed with multiple mesenteric lymphadenopathy }\end{array}$ \\
\hline Chest Xray - PA view & Right sided pleural effusion (Figure 1) \\
\hline CT - abdomen and pelvis & $\begin{array}{l}\text { Ascites with right pleural effusion with mesenteric } \\
\text { adenopathy (Figure 2) }\end{array}$ \\
\hline
\end{tabular}

Fig.1 Chest X Ray showing Right sided Pleural effusion

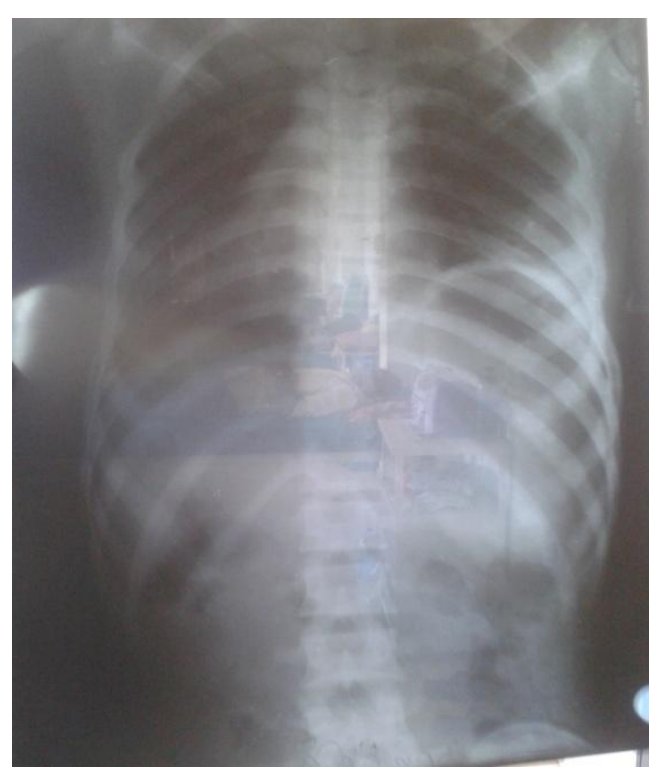


Fig.2 CT Abdomen \& Pelvis - Ascites with right pleural effusion with mesenteric adenopathy.

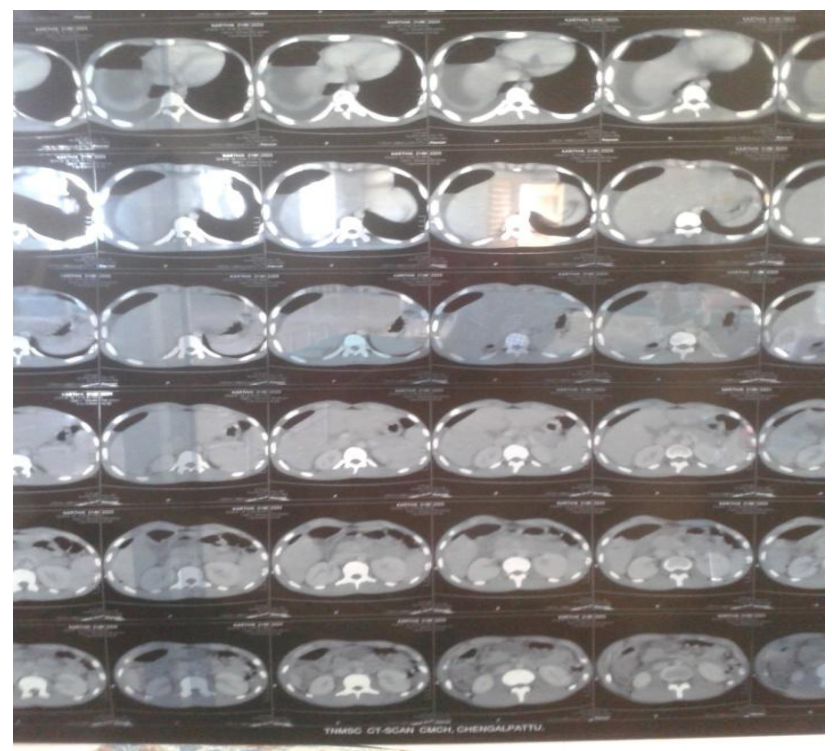

Fig.3 Direct Gram staining, numerous pus cells with abundant gram negative bacilli were seen

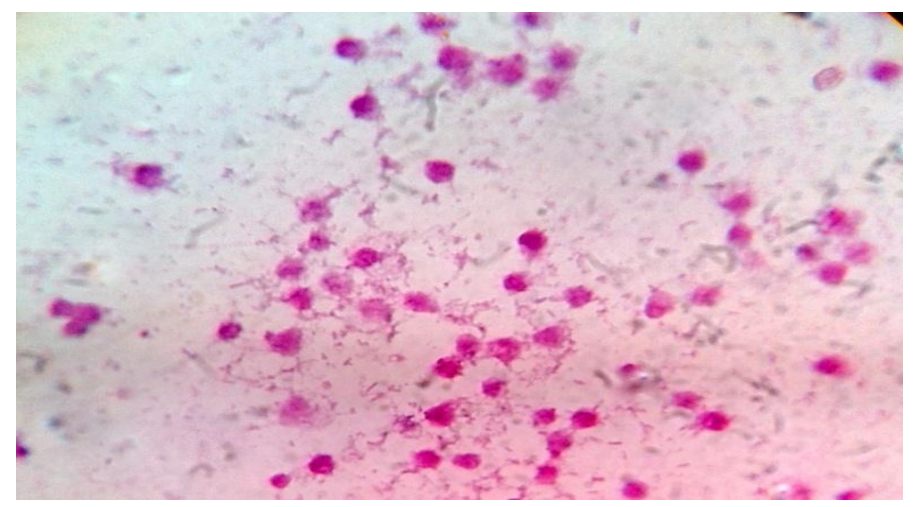

Fig.4 Antimicrobial Susceptibility test of the isolate

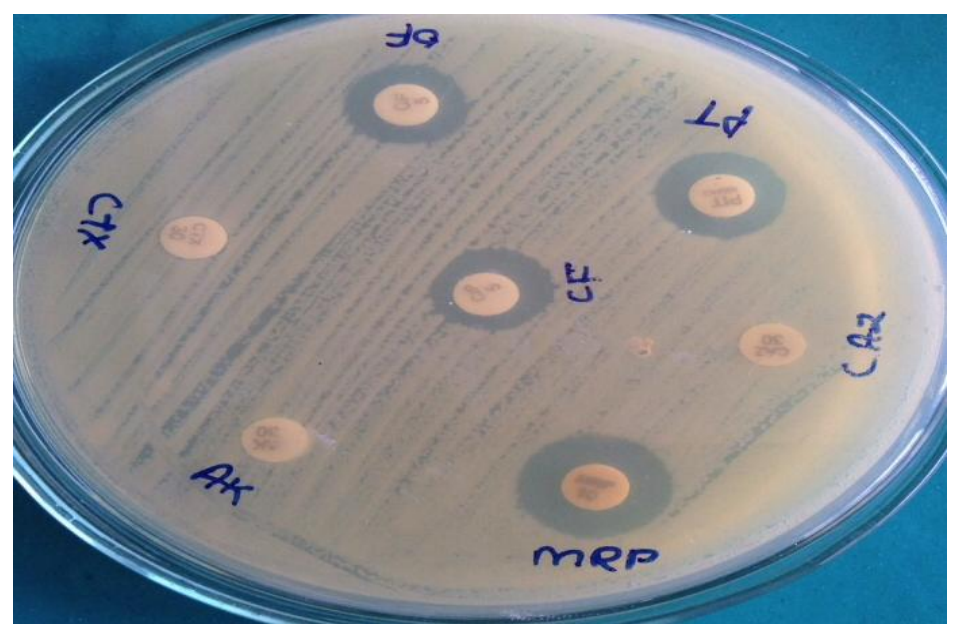


Fig.5 ESBL detection by double disk method

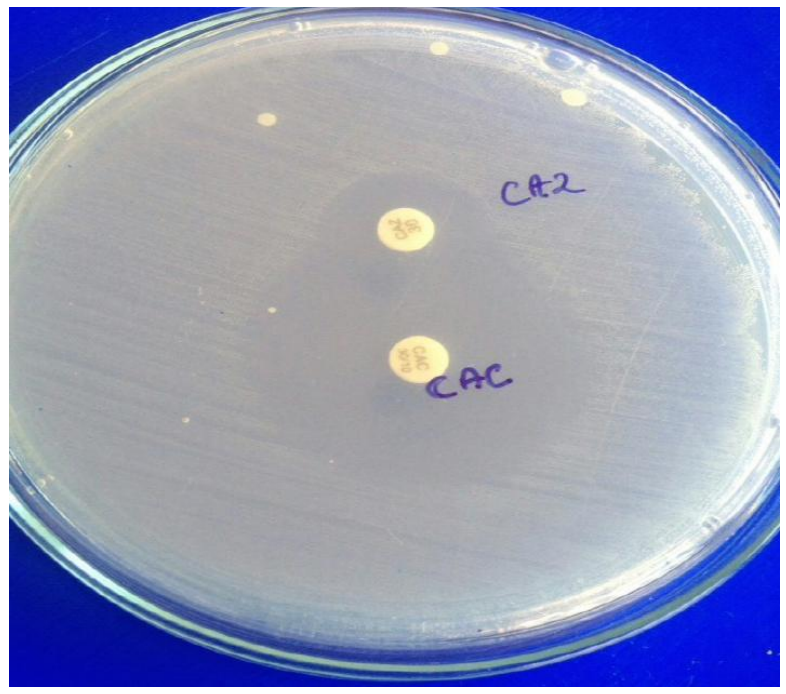

In conclusion, the vicious cycle of poor presenting symptoms and signs, delayed diagnosis and inappropriate antibiotic therapy adversely affects the prognosis of the patient in pleural infections. Hence it is advisory to do early diagnostic thoracentesis in all pleural fluid collections with an appropriate protocol to avoid delay in the diagnosis, treatment and to prevent the evolution of resistant strains.

\section{References}

Bryant, R.E., Salmon, C.J. 1996. Pleural empyema. Clin. Infect. Dis.

Burgos, J., Falcó, V., Pahissa, A. 2013. The increasing incidence of empyema. Curr. Opin. Pulm. Med.
Brims, F.J.H., S.M. Lansley, G.W. Waterer, Y.C.G. Lee. 2010. Empyema thoracis: new insights into an old disease, European Respiratory Rev., 19(117) 220-228; DOI: 10.1183/09059180. 00005610 .

Kundu et al. 2010. Adult thoracic empyema: A comparative analysis of tuberculous and non-tuberculous etiology in 75 patients. Lung India Off Organ Indian Chest Soc.

Nick, A., Maskell, Sarah, Batt, Emma, L., Hedley, Christopher, W.H., Davies, Stephen, H., Gillespie, Robert, J.O., Davies. 2006. The Bacteriology of Pleural Infection by Genetic and Standard Methods and Its Mortality Significance, American J. Respiratory and Critical Care Med., 174: 7.

\section{How to cite this article:}

Malathi Murugesan, Vijayalakshmi Arumugam and Nithya Gomatheswari. 2016. Escherichia coli in Pleural Empyema - An Uncommon Isolation. Int.J.Curr.Microbiol.App.Sci. 5(8): 75-79. doi: http://dx.doi.org/10.20546/ijcmas.2016.508.009 